\title{
Household Poverty Dimensions Influencing Forest Dependence at Volcanoes National Park, Rwanda: An Application of the Sustainable Livelihoods Framework
}

\author{
Ian E. Munanura1 ${ }^{*}$, Kenneth F. Backman1, DeWayne D. Moore², Jeffrey C. Hallo', \\ Robert B. Powell1 \\ ${ }^{1}$ Department of Parks, Recreation and Tourism Management, Clemson University, Clemson, SC, USA \\ ${ }^{2}$ Department of Psychology, Clemson University, Clemson, SC, USA \\ Email: *imunanu@clemson.edu
}

Received 19 October 2014; revised 20 November 2014; accepted 3 December 2014

Copyright (C) 2014 by authors and Scientific Research Publishing Inc.

This work is licensed under the Creative Commons Attribution International License (CC BY).

http://creativecommons.org/licenses/by/4.0/

c) (i) Open Access

\begin{abstract}
This paper explores the perceived relationship between household poverty and forest dependence among the poorest residents neighboring Volcanoes National Park in Rwanda. Using the sustainable livelihoods framework, this paper examines the influence of household poverty on forest dependence. The findings reveal that food and health security risks are primary drivers of forest dependence. Education security risks however, were found to have an indirect influence. Both food and health security risks were found to have equal influence on forest dependence. The economic security risks traditionally believed to significantly influence forest dependence were not found to have a direct influence.
\end{abstract}

Keywords

Household Poverty, Sustainable Livelihoods, Forest Dependence

\section{Introduction}

The relationship between poverty and forest dependence has been explored extensively [1]-[13]. However, evidence exists of knowledge gap and need for more identification of the links between poverty and forest dependence [7] [14]. This knowledge gap has been attributed to two main problems. First, poverty and forest depen-

${ }^{*}$ Corresponding author.

How to cite this paper: Munanura, I.E., Backman, K.F., Moore, D.D., Hallo, J.C. and Powell, R.B. (2014) Household Poverty Dimensions Influencing Forest Dependence at Volcanoes National Park, Rwanda: An Application of the Sustainable Livelihoods Framework. Natural Resources, 5, 1031-1047. http://dx.doi.org/10.4236/nr.2014.516087 
dence are both complex concepts to conceptualize [14]-[16]. Secondly, attempts to explore the relationship between poverty and forest dependence have been unsystematic [9] [17]. Evidence exists that due to conceptualization complexities, the relationship between poverty and forest dependence must be systematically examined using robust and reliable techniques that can enable replication and comparison [10] [17]. Most studies that have attempted to examine the relationship between poverty and forest dependence have primarily relied on quantifiable measures of poverty [4] [18]-[20]. However as reference [16] suggests, many aspects of poverty are not captured by quantifiable income and consumption variables. Overreliance on such quantifiable measures has led to only a partial understanding of the relationship between poverty and forest dependence. It has been posited that in fact, it is the unquantifiable measures of poverty that significantly drive forest dependence and biodiversity loss [2] [10].

The sustainable livelihoods (SL) approach commonly used as a framework to conceptualize poverty in international development provides us with a more holistic conceptualization of poverty [21]-[24]. It allows us to view poverty broadly, by considering its quantifiable and unquantifiable measures framed within the intrahousehold living conditions [21]-[24]. SL framework is emerging as a systematic approach to study the relationship between forest dependence and poverty [2] [5] [25] [26]. In this paper, we use SL as a theoretical framework and the validated household poverty and forest dependence (HPFD) Index to identify household poverty dimensions that influence forest dependence at Volcanoes National Park (VNP) in Rwanda. Since forest dependence represents multiple meaning at varying scales [15], it is by definition in this study, limited to the use of forest resources by local residents for subsistence needs. The unit of analysis is limited to the household level because it is viewed as the basic unit of production and where the most important family decisions are made [17].

This study was carried out at VNP in Rwanda for two main reasons. First, VNP is one of the three parks in the world that is inhabited by mountain gorillas, one of the most endangered species in the wild, and whose habitat is threatened by forest dependence [27]-[29]. There are only 380 remaining mountain gorillas in the Virunga Volcanoes [30], and their habitats, such as VNP, must be protected to avoid extinction. Second, there are many community enterprise and poverty alleviation programs at VNP aimed at addressing the forest dependency problem. However, their conservation impact has been challenged [27] [28]. In fact, similar programs in the form of Integrated Conservation and Development programs aimed at addressing poverty to reduce biodiversity loss have not been successful [31]-[34]. With the use of the HPFD Index grounded in the SL framework, this study presents a unique opportunity to identify dimensions of household poverty among residents in proximity to VNP, from which effective forest dependence and biodiversity loss remedial actions can be proposed.

The goal of this paper therefore was to examine and reveal the dimensions of household poverty perceived to influence forest dependence among poor residents neighboring VNP in Rwanda to inform conservation policy. Two key objectives are of interest. First, this paper aims to determine the dimensions of household poverty perceived to influence forest dependence by the poor households neighboring VNP. It further examines the perceived dimensions of household poverty with greater influence on forest dependence.

\section{Literature Review}

\subsection{Sustainable Livelihoods Framework and the Poverty Concept}

Poverty is a complex and multidimensional concept [16] Some authors have defined and viewed it from an economic perspective [9] [35] [36] while others have defined it from the wellbeing perspective [21] [24]. In fact, evidence exists to support the use of both perspectives in defining and measuring poverty [1] [2].

Traditionally, poverty has been conceptualized as having insufficient income to meet the basic needs of a household [36]. It is not surprising that the definition and measurement of poverty has been largely limited to income, wealth, and consumption [2]. However, these measures of poverty are biased towards urban conditions and explain little about the realities of the rural poor [37]. From the perspective of a rural and remote areas of a developing country, poverty is a complex, dynamic, and multidimensional construct involving material deprivation, lack of access to basic needs, and social inequality [16] [37]. To understand poverty, there is a need to move beyond macroeconomic measures such as income, which are more applicable at a national, rather than a village or household levels.

The literature suggests that through the SL framework, poverty can be better understood from a household 
perspective [3] [12] [38]. Chambers' work on sustainable livelihoods in the mid-1980s has generated debate over the years on the construction of poverty from a household perspective [16] [21] [24] [39]. This debate has significantly advanced the conceptualization of poverty from an income and/or assets-based phenomenon to a multidimensional concept of sustainable livelihoods encompassing, not just income, but also the capabilities of a household to maintain means of living. The SL approach, therefore, has evolved as a framework through which poverty can be better understood [21]. One of its key attributes is that it adds unquantifiable or non-material aspects of a household's or an individual's wellbeing to the poverty definition [2] [21].

Reference [19] defined livelihood as a means of making a living, comprised of capabilities, assets, and resources used in daily activities. It has become an important approach for defining poverty, because of its emphasis on the means of maintaining a living, which allows for a broader definition of poverty [13]. The sustainable livelihoods' framework, as defined above, has been further operationalized and widely applied in poverty alleviation discussions and intervention in developing countries. For example, CARE international has developed a Human Livelihood Security (HLS) Index to measure poverty for humanitarian and development intervention [39]. CARE's HLS framework takes a multidimensional approach to measure livelihood security through indicators such as food security, health security, education security, economic security, and empowerment [39]. Oxfam has also operationalized the concept of sustainable livelihood from economic, social, institutional, and ecological perspectives [38]. While there are operational variations, the underlying multidimensional outcomes of SL, such as food, health, education and economic security, are commonly agreed upon. In this paper, we use these multiple dimensions and their validated measures from the HPFD Index.

\subsection{Forest Dependence Construct}

Residents neighboring parks in developing countries have historically depended on forest resources for livelihoods in times of scarcity [4] [10] [20]. Forested areas, especially those in the tropics, provide multiple benefits, such as exploitation of the resources for commercial purposes, tourism services, harvests of non-timber forest products (NTFPs), harvests for subsistence livelihood needs, and ecological services [15] [41] [42]. For most poor households in proximity to forested areas, the forests harbor resources from which they derive their subsistence livelihoods [6]. For example, they hunt for meat and harvest resources such as wood, NTFPs, and medicinal plants for both household use and income [10] [11] [18]. In countries like Rwanda, with high population density and limited farmland, households adjacent to forests commonly rely on forest resources to supplement their livelihoods [4]. In some cases, it is the only source of livelihood for those households that have no farmland [27].

While such forest-based livelihoods are important to the poor and vulnerable, they also are believed to be the primary drivers of biodiversity loss in developing countries [4] [18] [43]. In most developing countries, such forest dependent activities have become a source of conflict between local communities and government officials responsible for conservation [32] [42]. These conflicts are inevitable because dependence on forest resources is unsustainable in the face of increasing biodiversity loss in developing countries [8]. For this reason, forest dependence has become an important aspect of conservation in developing countries. As a result, several authors have called for a better understanding of drivers of forest dependence in order to manage it effectively [4] [20].

Theoretically, forest resource dependence has been conceptualized as a multifaceted construct with multiple temporal and spatial dimensions [15]. For example, forest use results in multiple forms of commercial exploitation, recreational services, harvests of NTFPs, and subsistence livelihoods [15]. These forms of dependence operate and react differently at multiple levels—regional, national, community, household and individual [15]. The implication for multiple forms of forest dependence on these different levels is that forms of forest dependence and the unit of analysis have to be clearly defined to avoid ambiguity. Reference [10] proposed a conceptual framework for assessing the link between livelihoods and conservation from which forest dependence can be understood. In Salafsky and Wollenberg's framework, forest dependence can be viewed through multiple dimensions of livelihood dependence on species, on forest habitat resources, as well as space and time of use [10]. In the model of forest dependence hypothesized in this study (see Figure 1), we limit forest dependence to animal species and habitat resources dependence because they are regarded as primary dimensions in the Salafsky and Wollenburg framework [10], and are key indicators of biodiversity loss in developing countries [5] [43]. 


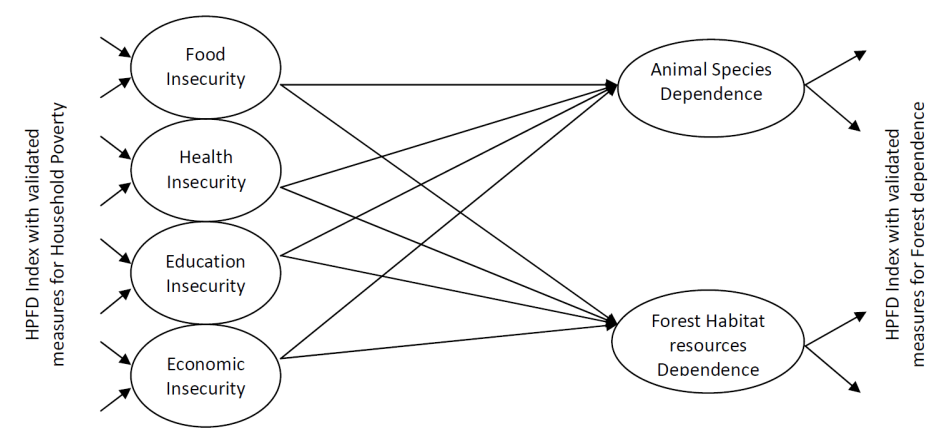

Figure 1. Hypothesized model of the relationship between household poverty and forest dependence.

Indicators of forest dependence can be seen in multiple forms. For example, the poor residents who depend on forests for subsistence livelihoods engage in activities such as bush meat hunting as well as forestland encroachment for farming [44] [45]. Other subsistence-based forest activities of poor residents who live in proximity to forests include harvests of NTFPs such as fuel wood, non-wood, and wood construction and handicraft-making materials and traditional medicine [13]. Evidence also exists that tropical forests are common sources of honey and water [46]. In this paper, we use the forest dependence indicators identified in the HPFD Index as valid measures of forest dependence at VNP.

\subsection{Poverty and the Forest Dependence Relationship}

The relationship between poverty and forest dependence has been extensively explored [1] [2] [4] [5] [10] [11]. From these studies, there is evidence to suggest that a correlation exists between poverty and human forest dependence behavior, which, in turn, results in biodiversity loss [4] [9] [17] [18]. It is also believed that alleviation of poverty reduces the degradation of biodiversity [7]. In fact, reference [9] refers to this as the "vicious cycle of poverty and environment relationship".

Forest dependence among the poor in developing countries is commonly attributed to limitations, such as farmland scarcity and fragmentation, poor productivity of land as soil quality declines, and a lack of alternative sources of livelihood [18]. In some cases, economically enabled individuals are also known to influence forest dependence through fiscal, and political power [2] [25]. This is common when interests in forest resources are of commercial value. In resource deficient and highly populated developing countries, especially in Africa, forest dependence is largely driven by the subsistence livelihood needs [11] [47]. In a study done by Masozera and Alavalapati [4], for example, rural poverty was found to highly influence forest dependence at Nyungwe National Park in Rwanda.

Despite the significant efforts made in both theory and practice, the link between poverty and forest dependence is still unclear [13]. One of the reasons for this is the poor understanding and conceptualization of poverty as a multidimensional phenomenon. Attempts to address this gap have led to the adaptation of the SL approach to establish the linkage between poverty and forest dependence [3] [5]. SL has been widely used to understand the relationship between poverty and biodiversity conservation, because it adds non-material aspects of a household's or an individual's wellbeing to the poverty definition [3] [12] [13]. In fact, reference [13] posits that managing biodiversity conservation effectively requires paying close attention to the livelihoods of residents in areas neighboring the forest areas.

It must be understood, however, that the effect of household livelihoods on forest dependence varies. To understand the relationship between poverty and forest dependence and in recognition of the existing gaps in literature, we must assess how different dimensions of poor household livelihoods influence or interact to influence forest dependence [10]. To do this effectively, we must systematically define, measure, and provide direct linkages between poverty and forest dependence [10]. Using SL framework, a model of the poverty and forest dependence relationship is hypothesized in Figure 1. Conceptually, it is designed as a Multiple Indicator and Multiple Causes (MIMIC) model for identification purposes, given the formative nature of livelihood indicators [48] [49]. Primarily however, a MIMIC model allows a clear view of the direct causal effect of each dimension of household poverty and each dimension of forest dependence. 


\section{Methodology}

\subsection{Research Design}

This study was done in three phases following an exploratory sequential mixed methods design [50]. Phase one was carried out in September 2012, and it involved an exploratory evaluation of perceptions of key stakeholders including local residents with access to tourism benefits, local residents without access to benefits and park officials. The aim of this phase was mainly to explore using focus group interviews, the meaning of poverty and forest dependence from the local context. The results from the focus group interviews were then used to inform the design of phase two and to interpret phase three results. In phase two, a survey was done in April 2013 to validate the HPFD Index. The validated measures of the HPFD Index were then used to design an instrument that was administered in phase three during the months of June and July 2013. This survey was intended to use the HPFD Index to evaluate the relationship between household poverty and forest dependence relationship, which is the focus of this paper [50].

\subsection{Participant Selection}

The target population of this study was the local residents in absolute poverty, whose households neighbor VNP. In Rwanda, poverty is classified into three categories-poverty, extreme poverty and absolute poverty [51]. The latter is the lowest categorization of poverty, where a household has no land or whose land is insufficient to meet the basic livelihood needs and relies on farm wage work to maintain a living [51]. The sample selection of participants was narrowed from all the households in absolute poverty adjacent to the park to only those in Kinigi sector. Kinigi sector was selected out of four administrative sectors neighboring the park because it has higher incidences of illegal forest resource use activities at VNP. The selection of participants was limited to four administrative cells in Kinigi sector that are adjacent to the park including Nyabigoma, Nyonirima, Kaguhu, and Bisoke cells. From each cell, a list of extremely poor household heads in the respective cells was obtained from local leaders, who have all community residents classified according to their social-economic status. Four lists were labeled, combined and numbered to form a sampling frame for this study. Following the suggestion of Dillman and colleagues, a systematic random sampling was used to select participants from the sampling frame using a random interval of 4 [52]. A sample of 322 participants was finally selected to participate in this study.

\subsection{Instrument Design, Pretesting and Data Collection}

The instrument used in this study was developed from the phase two validated HPFD Index presented in Table 1. Following DeVellis' guidelines for writing clear and unambiguous indicator statements, measurement indicators making up the HPFD Index were rewritten in clear and concise belief statements that local residents could understand [53]. For each belief statement representing a measurement indicator, a response format was created using a seven-point Likert scale where 1 represented Strongly Disagree and 7 represented Strongly Agree. The developed instrument was pretested on a group of 10 residents who were in the same category as the targeted participants. A few indicators were rewritten to address the uncertainty that was observed during pretesting. The instrument was implemented with the support of 10 assistants who reside in the same area. These assistants were trained and practiced using mock interviews among themselves to ensure that they all understood the content and potential problems they might encounter during interviews. The use of interviewers in data collection was selected as the most effective approach because most participants cannot read and write.

Use of interviewers in data collection allowed maximization of response rates, enabled the clarification of questions, and assured confidentiality for participants. However, the interviewer-administered approach to a survey has the potential for interviewer bias [54]. To manage such potential bias, three steps were taken, following reference [52] guidelines. First, an interview protocol was developed to guide interviewers in data collection. This protocol was one of the tools used during interviewer training and the instrument pretesting exercise, and also served as a reference document during data collection. Second, interviewers were trained before the survey. Following their training, an instrument pretesting exercise allowed the researcher to select assistants who exhibited a good understanding of required tasks and aptitude to be able make good judgments. Third, the researcher closely worked with interviewers during the survey and monitored them during interviews. Additionally, completed instruments were reviewed overnight to identify anomalies that could be discussed the next day of data collection in order to limit recurrence. 
Table 1. Validated household poverty and forest dependence (HPFD) Index at VNP.

\begin{tabular}{|c|}
\hline Validated measures of multiple dimensions of poverty and forest dependence constructs \\
\hline Economic insecurity dimension of poverty \\
\hline 1. We don't have livestock assets in our household \\
\hline 2. Our land is no longer productive \\
\hline 3. Our agricultural yield is not sufficient because of crop-raiding by animals from the park \\
\hline 4. We don’t have skills in our household to create jobs \\
\hline Food insecurity dimension of poverty \\
\hline 5. We regularly don't eat food we prefer in our household \\
\hline 6. We regularly don't eat enough food for everyone in our household \\
\hline 7. We regularly don't eat three times in a day \\
\hline 8. The annual food production for our household is insufficient \\
\hline Health insecurity dimension of poverty \\
\hline 9. Health care facilities are far from our household \\
\hline $\begin{array}{l}\text { 10. We don't have money to pay for the national health insurance plan } \\
\text { "We do not have access to clean water for use in our household }\end{array}$ \\
\hline Education insecurity dimension of poverty \\
\hline 11. Adults in our household cannot read and write \\
\hline 12. Our children do not study because they don’t have the required scholastic materials \\
\hline 13. Our children do not study because they don't have food at home \\
\hline Dependence on animal species \\
\hline \multirow{2}{*}{$\begin{array}{l}\text { 14. Some people in our community go to the park to hunt animals for bush-meat to feed their families } \\
\text { 15. Some people in our community go to the park to hunt animals for bush-meat to sell and earn income } \\
\text { "Some people in our community go to the park to hunt animals for bush-meat for medicinal use in our home }\end{array}$} \\
\hline \\
\hline Dependence on forest habitat resources \\
\hline 16. Some people in our community go to the park to collect bamboo for household use \\
\hline 17. Some people in our community go to the park to collect bamboo for sell and earn income \\
\hline 18. Some people in our community go to the park to collect wood for crop support in their agricultural fields \\
\hline 19. Some people in our community go to the park to collect honey \\
\hline 20. Some people in our community go to the park to collect handicraft-making materials \\
\hline
\end{tabular}

Note: Each statement was measured on a seven-point Likert response scale, where 1 represents Strongly Disagree and 7 represents Strongly Agree. "Statements with an asterisk were added to the Index for variable identification purposes [55].

\subsection{Data Analysis}

Data analysis for the household poverty and forest dependence construct relationship was done in two stages of pre-analysis and model testing. The pre-analysis stage was aimed at stabilizing parameter estimates, and involved data screening using the SPSS software package to identify outlier effects and assessment of univariate and multivariate normality assumptions [56]. Missing values that are normally of concern at this stage, were not in this study because the instrument was interviewer-administered, which enabled full survey completion. Five cases were excluded from the analysis because they were found to be extreme multivariate outliers [56]. Upon data cleanup and stabilization, a total of 317 usable cases (samples) were then employed, through a Structural Equation Modeling process, for the hypothesized measurement model testing and to examine coefficients of the hypothesized causal and direct effect construct relationships [56]. The model testing was run in the EQS software (version 6.2) using CFA for measurement and structural modeling [55].

The CFA was used as a measurement model to determine the level of relationships and covariances in the 
poverty and forest dependence construct relationships [55]. CFA was also used to identify interrelationships between measured scales and latent constructs [56]. The Structural Equation Modeling procedure in this study therefore followed the recommended steps of model specification and estimation, testing model fit, and modification [55] [56]. Model estimation was performed using the Maximum Likelihood (ML) parameter estimation method [55]. The aim of using ML model estimation was to be able to observe the level of discrepancy shown by residuals between sample and population covariances implied by the hypothesized model [55]. Following review of residuals in covariance matrices for evidence of model misspecification [55], the hypothesized model was then tested for goodness-of-fit was performed using Chi-square tests, Comparative Fit Index (CFI), NonNormed Fit Index (NNFI) and Root Mean Squared Error of Approximation (RMSEA) [55] [57]. Both CFI and RMSEA are recommended in literature as considerably better indices for as assessing model fitness [55]. CFI is valued for the consideration of sample size effect [55], while RMSEA is valued for the consideration of the number of estimated parameters in the model [55] [57]. The examination of the goodness-of-fit of a hypothesized model was performed and considered realistic when the CFI values were within the desirable range of 0.90 and above, with RMSEA values ranging below 0.08 [55]. The goodness of fit examination was aimed at determining whether the model is reflective of sample data. When this was confirmed, standardized parameter estimates were used to examine effect size in the hypothesized model [55]. Where the goodness-of-fit was found to be implausible (CFI < 0.90, RMSEA > 0.08), modifications were performed based on Lagrange Multiplier Test (LM Test) results that have strong theoretical justifications [55] [57].

\section{Results}

\subsection{Sample Description}

Gender, age, marital status, primary education attainment, income, livestock asset ownership, shelter availability and status, farmland ownership, and number of children in a household and their school attendance measured the characteristics of the sample. Using nominal scale responses, participants were asked to select a scale that best fit their response. A summary of demographic information on this sample is provided in Table 2. Demographic results, in brief, shows that a majority of participants were married (>93\%), under the age of 30 years with about 4 children per household. A little over 18 percent of the sample had between 5 and 9 children in each household. Over 60 percent were women and more than 75 percent of participants had no basic primary education. The level of poverty was high among participants, as indicated in the table. For example, most of the participants (62.8 percent) earned less than 10,000 Rwandan Francs (approximately 15 US dollars) per month, and over 31 percent did not earn any income at all. Over 85 percent did not have basic livestock assets such as chickens or goats, and about 60 percent did not have land for cultivation. Almost 90 percent of participants live in incomplete shelters, and of these households, 62.5 percent did not send their children to school.

\subsection{Dimensions of Household Poverty Perceived to Influence Forest Dependence at VNP}

Confirmatory Factor Analysis was used to statistically assess the hypothesized measurement model presented in Figure 1. Goodness of fit for the model was examined to ensure that the hypothesized model was acceptable and consistent with sample data [56]. The initial assessment showed an indication of some degree of misfit in the hypothesized model, as CFI and RMSEA values were in the lower bounds of the plausible range of model fitness $(\mathrm{CFI}=0.902$, RMSEA $=0.08)$. To detect the potential source of misfit, LM Test results were examined to identify univariately the misfitting parameters with a sharp drop in Chi-square [55]. Following univariate test results, error covariances between harvests for crop support wood and harvests of bamboo wood for subsistence use, hunting bush meat for medicinal use and hunting bush meat for subsistence use, as well as between harvests of bamboo wood for subsistence use and hunting bush meat for income were specified. The model was re-estimated and indicated plausible fit $(\mathrm{CFI}=0.95$, RMSEA $=0.058)$.

Following the examination of model fitness, the hypothesized structural relationships were examined and the results are presented in Table 3. They indicate that food insecurity (H1a; $\beta=0.190, \mathrm{p}<0.05 ; \mathrm{H} 1 \mathrm{~b} ; \beta=0.297, \mathrm{p}$ $<0.05$ ) and health insecurity (H2a; $\beta=0.187, \mathrm{p}<0.05$; H2b; $\beta=0.264, \mathrm{p}<0.05$ ) are two household poverty dimensions that influence both forest dependence dimensions of dependence on animal species and dependence on forest resources. Results also demonstrate that both education insecurity (H3a; $\beta=0.234, \mathrm{p}>0.05$; H3b; $\beta=$ $0.092, \mathrm{p}>0.05$ ) and economic insecurity (H4a; $\beta=-0.924, \mathrm{p}>0.05 ; \mathrm{H} 4 \mathrm{~b} ; \beta=-0.844, \mathrm{p}>0.05$ ) do not significantly influence either forest dependence dimensions. 
Table 2. Description of the sample that participated in the survey at VNP $(n=317)$.

\begin{tabular}{|c|c|c|}
\hline Variables & Frequency & Valid percent (\%) \\
\hline \multicolumn{3}{|l|}{ Civil status } \\
\hline Single & 20 & 6.3 \\
\hline Married & 297 & 93.7 \\
\hline \multicolumn{3}{|l|}{ Age } \\
\hline$<29$ & 107 & 33.8 \\
\hline $30-39$ & 75 & 23.7 \\
\hline $40-49$ & 61 & 19.2 \\
\hline $50-59$ & 41 & 12.9 \\
\hline$>60$ & 33 & 10.4 \\
\hline \multicolumn{3}{|l|}{ Education } \\
\hline Attained primary education & 77 & 24.3 \\
\hline No primary education & 240 & 75.7 \\
\hline \multicolumn{3}{|l|}{ Gender } \\
\hline Male & 120 & 37.9 \\
\hline Female & 197 & 62.1 \\
\hline \multicolumn{3}{|c|}{ Household income per month in Rwandan Francs (1 US\$ = 650 RwF) } \\
\hline No income & 101 & 31.9 \\
\hline $1-10,000$ & 199 & 62.8 \\
\hline $10,001-20,000$ & 13 & 4.1 \\
\hline$>20,000$ & 4 & 1.3 \\
\hline \multicolumn{3}{|l|}{ Livestock asset ownership } \\
\hline Own livestock (goat, chicken) & 47 & 14.8 \\
\hline No asset owned & 270 & 85.2 \\
\hline \multicolumn{3}{|l|}{ Shelter status } \\
\hline Complete & 32 & 10.1 \\
\hline Incomplete & 285 & 89.9 \\
\hline \multicolumn{3}{|l|}{ Farmland ownership } \\
\hline Own land & 126 & 39.7 \\
\hline Do not own land & 191 & 60.3 \\
\hline \multicolumn{3}{|l|}{ Number of children in a household } \\
\hline No children & 28 & 8.8 \\
\hline $1-4$ & 227 & 71.6 \\
\hline$>5$ & 62 & 19.6 \\
\hline \multicolumn{3}{|l|}{ Children school attendance } \\
\hline Children attend school & 119 & 37.5 \\
\hline Children do not attend school & 198 & 62.5 \\
\hline
\end{tabular}


Table 3. Summary of hypotheses testing results.

\begin{tabular}{|c|c|c|c|}
\hline Hypotheses & $\begin{array}{c}\text { Unstandardized } \\
\text { parameter effects }\end{array}$ & $\begin{array}{c}\text { Standardized } \\
\text { parameter effects }\end{array}$ & Results \\
\hline $\begin{array}{l}\text { H1a. Forest insecurity has a significant influence on } \\
\text { dependence on animals species among poor households } \\
\text { neighboring VNP }\end{array}$ & $\mathrm{B}=0.296(0.116)^{1}$ & $\beta=0.190$ & Supported \\
\hline $\begin{array}{c}\text { H1b. Forest insecurity has a significant influence on } \\
\text { dependence on forest resources among poor households } \\
\text { neighboring VNP }\end{array}$ & $\mathrm{B}=0.445(0.136)^{1}$ & $\beta=0.297$ & Supported \\
\hline $\begin{array}{c}\text { H2a. Health insecurity has a significant influence on } \\
\text { dependence on animals species among poor households } \\
\text { neighboring VNP }\end{array}$ & $\mathrm{B}=0.296(0.116)^{1}$ & $\beta=0.190$ & Supported \\
\hline $\begin{array}{l}H 2 \boldsymbol{b} \text {. Health insecurity has a significant influence on } \\
\text { dependence on forest resources among poor households } \\
\text { neighboring VNP }\end{array}$ & $\mathrm{B}=0.175(0.045)^{1}$ & $\beta=0.264$ & Supported \\
\hline $\begin{array}{c}\text { H3a. Education insecurity has a significant influence on } \\
\text { dependence on animals species among poor households } \\
\text { neighboring VNP }\end{array}$ & $\mathrm{B}=0.083(0.101)^{2}$ & $\beta=0.234$ & Not supported $^{1}$ \\
\hline $\begin{array}{c}\text { H3b. Education insecurity has a significant influence on } \\
\text { dependence on forest resources among poor households } \\
\text { neighboring VNP }\end{array}$ & $\mathrm{B}=0.032(0.045)^{2}$ & $\beta=0.092$ & Not supported $^{1}$ \\
\hline $\begin{array}{c}\text { H4a. Economic Insecurity has a significant influence on } \\
\text { Dependence on Animals Species among poor households } \\
\text { neighboring VNP }\end{array}$ & $\mathrm{B}=-0169(0.142)$ & $\beta=-0.924$ & Not supported \\
\hline $\begin{array}{c}\text { H4b. Economic insecurity has a significant influence on } \\
\text { dependence on forest resources among poor households } \\
\text { neighboring VNP }\end{array}$ & $\mathrm{B}=-0.148(0.127)$ & $\beta=-0.844$ & Not supported \\
\hline
\end{tabular}

${ }^{1}$ Hypothesis supported by consideration of direct effects; ${ }^{2}$ Hypothesis supported after consideration of indirect effects (see Table 4).

Results of the hypothesis testing for the relationship between household poverty and forest dependence in Table 3 above were based on direct effects. However, there is evidence that without a closer examination of indirect effects, understanding the relationship under investigation may be limited [56]. Conversely, indirect parameter effects associated with each measure of the four household poverty dimensions were examined to identify measures with significant indirect relationships with forest dependence.

Results in Table 3 indicate quantifiable measures of the four household poverty dimensions with potential to influence indirectly both forest dependence dimensions. As seen earlier, only two dimensions of household poverty (food and health insecurity) were found to have a direct influence on forest dependence, as indicated in Table 3. However, a closer examination of indirect effects in Table 4, reveals that two of the measures for the education insecurity construct (high adult illiteracy and limited access to scholastic materials for children from poor households) may also indirectly contribute to forest dependence. Additionally, results also indicate two quantifiable measures of food insecurity (insufficient annual production of food and skipping meals frequently) and two measures of health insecurity (inability to access healthcare centers and unavailability of clean water) significantly influence dependence on forest animals and resources for livelihoods among poor households neighboring VNP. Interestingly, the economic insecurity dimension of Household Poverty was not found to either directly or indirectly influence forest dependence at VNP, contrary to what is commonly believed locally.

From the above analysis, a structural model with the significant relationships was run to identify how each of the indicators-food insecurity, health insecurity and education insecurity-directly affect forest dependence dimensions as well as their indirect effects on the individual measures of both forest dependence dimensions obtained from the HPFD index. Results presented earlier reveal that the food insecurity, health insecurity and education insecurity influence forest dependence. When the indirect effects of household poverty on individual forest dependence indicators are examined, results presented in Table 4 reveal that food insecurity is the main cause of forest dependence, and this effect is attributed to both insufficient annual food production and the high frequency of skipping meals that are common among the poor households neighboring VNP. Additionally, results reveal that difficulty in accessing health care and high adult illiteracy rate are also among the key attributes of poverty that drives forest dependence among poor households neighboring VNP. 
Table 4. Unstandardized parameter effects between household poverty and forest dependence.

\begin{tabular}{|c|c|c|c|c|}
\hline \multirow{3}{*}{ Household poverty dimensions and indicators } & \multicolumn{4}{|c|}{ Forest dependence dimensions } \\
\hline & \multicolumn{2}{|c|}{ Dependence on animal species } & \multicolumn{2}{|c|}{ Dependence on forest resources } \\
\hline & $\begin{array}{l}\text { Direct effects } \\
\quad \text { (SE) }\end{array}$ & $\begin{array}{l}\text { Indirect effects } \\
\quad \text { (SE) }\end{array}$ & $\begin{array}{l}\text { Direct effects } \\
\text { (SE) }\end{array}$ & $\begin{array}{l}\text { Indirect effects } \\
\text { (SE) }\end{array}$ \\
\hline Food insecurity & $0.296(0.116)^{*}$ & & $0.445(0.136)^{*}$ & \\
\hline Eating non preferred food frequently (FI1) & & $0.012(0.103)$ & & $0.018(0.154)$ \\
\hline Eating inadequate food frequently (FI2) & & $0.084(0.118)$ & & $0.126(0.176)$ \\
\hline Skipping meals frequently (FI3) & & $0.332(0.139)^{*}$ & & $0.499(0.156)^{*}$ \\
\hline Insufficient annual production of food (FI4) & & $0.296(0.116)^{*}$ & & $0.445(0.136)^{*}$ \\
\hline Health insecurity & $0.130(0.045)^{*}$ & & $0.175(0.045)^{*}$ & \\
\hline Inability to access healthcare centers (HI1) & & $0.130(0.045)^{*}$ & & $0.175(0.045)^{*}$ \\
\hline $\begin{array}{l}\text { No access to government subsidized health care } \\
\text { program (HI2) }\end{array}$ & & $-0.049(0.035)$ & & $-0.066(0.045)$ \\
\hline Unavailability of clean water (HI4) & & $0.155(0.079)^{*}$ & & $0.209(0.095)^{*}$ \\
\hline Education insecurity & $0.083(0.101)$ & & $0.032(0.042)$ & \\
\hline High adult illiteracy rate (EDI1) & & $0.366(0.096)^{*}$ & & $0.139(0.343)$ \\
\hline $\begin{array}{l}\text { Access to scholastic materials for children } \\
\text { (EDI2) }\end{array}$ & & $-0.346(0.146)^{*}$ & $-0.452(0.143)^{*}$ & $-0.131(0.322)$ \\
\hline $\begin{array}{l}\text { Dropping out of school because of lack of food } \\
\text { (EDI4) }\end{array}$ & & & & $0.032(0.042)$ \\
\hline Economic insecurity & $-0.169(0.142)$ & & $-0.148(0.127)$ & \\
\hline Poor productivity of agricultural land (ECI1) & & $0.083(0.101)$ & & $0.253(0.422)$ \\
\hline Animal crop-raiding (ECI2) & & $0.090(0.154)$ & & $0.078(0.136)$ \\
\hline Lack of assets in livestock (ECI3) & & $-0.211(0.429)$ & & $-0.185(0.377)$ \\
\hline Lack of diverse income sources (ECI4) & & $-0.169(0.142)$ & & $-0.148(0.127)$ \\
\hline
\end{tabular}

*Total and indirect effects of household poverty on forest dependence is significant at 0.05 .

\subsection{Household Poverty Dimensions with Greater Influence on Forest Dependence}

To determine the household dimensions with greater influence on forest dependence, the structural model (Figure 2) was used as a baseline model to test for invariance of mean structures between each of the quantifiable measures of food insecurity, health insecurity, and education insecurity, and forest dependence constructs they were hypothesized to predict. The model was estimated and produced a good fit (CFI = 0.985; RMSEA $=0.045)$. Following the guidelines for testing invariance of mean structures, a fully constrained model was estimated, and direct relationships between six measures of each dimension of household poverty and forest dependence were fixed to equivalence [55] [56]. To test for invariance, change in Santora-Bentler Chi-square was examined along with the change in CFI as indicated in Table 5. The consideration of the change in CFI was based on the rationale that the sole use of change in Santora-Bentler Chi-square to evaluate invariance is impractical and should be considered along with change in CFI [55].

Both models were compared and the results presented in Table 5 reveal noninvariance $(\Delta \mathrm{S}-\mathrm{B} \chi 230.857 ; \Delta \mathrm{df}$ $=10 ; \mathrm{p}<0.01$ ). However consideration of change in Santora-Bentler Chi-square can be misleading [55]. When change in CFI is considered, results show the evidence of equivalence with a minimal change in CFI of 0.008, which is below the proposed level $(\Delta \mathrm{CFI}>0.01)$ for noninvariance [55]. Therefore, these results confirm that food insecurity, health insecurity, and education insecurity have equal effect on forest dependence and none of them has a greater influence or effect on either forest dependence dimensions. 


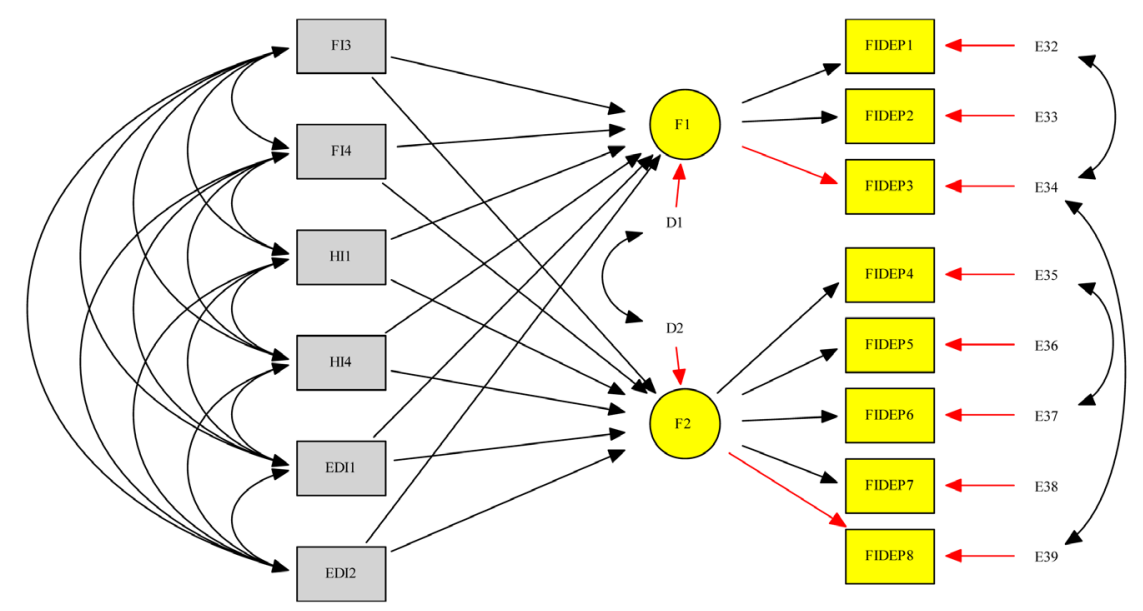

Household Poverty Dimensions and indicators

\section{Food Insecurity}

Skipping meals frequently (FI3)

Insufficient annual production of food (F/4)

Health Insecurity

Inability to access healthcare centers (HI1)

Unavailability of clean water (HI)

Education Insecurity

High adult illiteracy rate (EDI1)

Access to scholastic materials for children (EDI3)

$\begin{array}{cc}\text { F1 } & \text { F2 } \\ & \\ 0.120^{*} & 0.213^{*} \\ 0.154^{*} & 0.177^{*} \\ & \\ 0.179^{*} & 0.225^{*} \\ 0.108^{*} & 0.132^{*} \\ & \\ 0.261^{*} & 0.201^{*} \\ -0.109^{*} & -0.175^{*}\end{array}$

Forest dependence indicators FIDEP1 FIDEP2 FIDEP4 FIDEP5 FIDEP 6

$0.342 * 0.345^{*} \quad 0.310^{*} \quad 0.557^{*} \quad 0.614^{*}$ $0.451^{*} 0.454^{*} 0.408^{*} 0.476^{*} 0.526^{*}$

$\begin{array}{lllll}0.157^{*} & 0.158^{*} & 0.142 * & 0.180^{*} & 0.199 *\end{array}$ $\begin{array}{lllll}0.202 & 0.203 & 0.183 & 0.225 * & 0.248 *\end{array}$

$\begin{array}{lllll}0.471 * & 0.475 * & 0.426 * & 0.333 * & 0.367 *\end{array}$ $\begin{array}{lllll}-0.322 & -0.325 & -0.292 & -0.473^{*} & -0.522 *\end{array}$

Note; F1= Forest dependence on animal species construct, F2= Forest dependence on forest resources, FIDEP $1=$ Hunting bush meat for subsistence use, FIDEP2=Hunting bush meat for income, FIDEP4= Harvesting of Bamboo wood for subsistence use, FIDEP5= Harvesting Bamboo for income, FIDEP6= Harvesting Crop support wood in agricultural fields, FIDEP7=Harvests of Honey in the park, FIDEP8=Harvests of handicraft materials. FIDEP 7 and 8 are not included because they were not identified as key threats at VNP; * parameter effects significant at $p<0.05$.

Figure 2. Structural model with parameter effects of household poverty on forest dependence at VNP.

Table 5. Test of invariance on the effect of multiple dimensions of poverty on forest dependence.

\begin{tabular}{|c|c|c|c|c|c|c|c|c|c|}
\hline \multirow{2}{*}{ Hypothesized model } & \multicolumn{3}{|c|}{ Robust Statistics } & \multicolumn{3}{|c|}{ Scaled differences $^{1}$} & \multirow{2}{*}{ CFI } & \multirow{2}{*}{$\Delta \mathrm{CFI}$} & \multirow{2}{*}{$\begin{array}{c}\text { Models } \\
\text { compared }\end{array}$} \\
\hline & $\mathbf{S}-\mathbf{B} \chi^{2}$ & df & Prob & $\Delta \mathrm{S}-\mathrm{B} \chi^{2}$ & $\Delta \mathbf{d f}$ & Prob & & & \\
\hline $\begin{array}{l}\text { Model 1; Unconstrained baselir } \\
\text { model (six variables of } \\
\text { household poverty dimensions } \\
\text { predicting forest dependence) }\end{array}$ & 85.84 & 52 & $\mathrm{p}<0.05$ & 0 & 0 & 0 & 0.985 & 0 & \\
\hline $\begin{array}{l}\text { Model 2; Fully constrained } \\
\text { model (comparison of effects } \\
\text { resulted in } 10 \text { constraint pairs) }\end{array}$ & 114.9 & 62 & $\mathrm{p}<0.01$ & 30.8675 & 10 & $\mathrm{p}<0.01$ & 0.977 & 0.008 & $2 \mathrm{v} 1$ \\
\hline
\end{tabular}

${ }^{1}$ Scaled differences were calculated using the Santorra-Bentler Scaled Chi-square adjusted difference tests (Santorra \& Bentler, 2001); CFI = Comparative Fit Index; df = degree of freedom; S-B $\chi^{2}=$ Santorra-Bentler Scaled Chi-square; Prob = test of significance at $95 \%$ confidence interval.

\section{Discussion}

This study was conducted to determine the dimensions of household poverty perceived to influence forest dependence among poor residents neighboring VNP. The findings reveal that forest dependence at VNP is influenced primarily by food insecurity and health insecurity. It was also revealed that education insecurity in poor households contributes to forest dependent behavior, due to the high adult illiteracy rate and lack of scholastic materials that limit school attendance or leads to dropping out. The findings also reveal that insufficient annual food production and high frequency of meal skipping are primary indicators of food insecurity among the poor households neighboring VNP. Health insecurity, on the other hand, is primarily exposed by poor access to clean water and health care services. The findings on health and education security risks and their influence on forest dependency are in keeping with the SL premise that poverty should not only be viewed from an asset and in- 
come perspective, but also the capability of the household to meet and maintain wellbeing is equally important in understanding poverty and its impact [21] [39].

The key findings and contribution of this study are three-fold. First, this study provides an empirical justification for the importance of health and education in the debate on the relationship between poverty, forest dependence and biodiversity conservation, factors which have not been previously given due attention. Second, economic security of income and assets do not have a significant influence on forest dependence at VNP. This is surprising and in disagreement with current hypothesis in biodiversity conservation literature that argues that forest dependence is primarily a function of household income and asset needs [11] [12] [18] [58]. This finding questions the "asset poverty" concept in assessing the link between poverty and forest dependence [11] [12] [20] and supports the "welfare poverty" idea that is emerging, which views poverty from its structural context beyond income and assets [2] [6] [7] [9]. It reveals that there is more to poverty than income, employment, and household assets in its relationship with forest dependence. This could point to why most income and asset based interventions in the form of ICDPs have misdiagnosed the causes of biodiversity loss, which, as is evident in the literature, has led to failure [31]-[34].

Third, the finding that there is no difference on how food security, health security, and education security risks affect forest dependence is also surprising. While food security risks have featured prominently in poverty and forest dependence studies as part of the income and asset hypothesis [11] [12] [58], health and education risks have not. Yet, human health and education risks are considered as significant drivers of poverty in the development arena. In fact, they are both key components of international frameworks for sustainable development, such as the United Nations sustainable development Agenda 21 [59], and Millennium Development Goals [38] [60] [61]. Their absence or at least abstract consideration of health and education security risks in the poverty and forest dependence debate is surprising [17]. For example, the second goal of the MDG is to have all children in developing countries complete universal education by 2015 [38]. In fact, the MDG goals are predominantly focused on addressing human health challenges such as malaria, HIV Aids, child mortality and maternal health [61]. Agenda 21 also stipulates that for sustainable development to be achieved, primary human needs must be addressed [59]. Existence of such an international development policy framework is a demonstration of the global recognition of human health and education security risks as constraints to poverty mitigation and sustainable development efforts. While these livelihood security risks appear in the development debate, they are missing in the biodiversity conservation discourse [17].

Evidence exists that without education, the chances for a household to overcome poverty are limited, and the implications for wildlife are significant [7] [38]. Demographic results presented in Table 2, show that over 62 percent of children from poor households neighbor the park do not attend school. This poses a forest dependence and conservation concern for VNP in the light of the findings of the effect of education security risks on forest dependence. Most developing countries have introduced universal primary education and used net enrollment to justify the MDG targets [38]. However, constraints such as lack of scholastic materials observed in this study remain unnoticed, leading to high dropout rates among the poor, which drives them further into poverty. Evidence exists for a lack of scholastic materials as a significant education security risk [38] [61].

Proliferation of such education security risks not only worsens an already existing poverty situation, but also creates even a larger forest dependent constituency near wildlife areas. Therefore, practitioners involved in promoting wildlife conservation and the Rwandan government must put mechanisms in place to support keeping the poor children in school if school dropout rates and high adult illiteracy - both found to influence forest dependence-are to be overcome. For example, an education support system for poor households in areas neighboring the park could be set up and facilitated to identify and provide the educational materials that have been keeping children out of school. Evidence of perverse incentives such as children helping parents to earn a living rather than attend school, also exists in limiting children from poor households to attain education [38]. An education support system should investigate and address perverse incentives that may exist in addition to the creation of a scholastic materials support system. Since the creation of income-enabled and self-sufficient households is the only sustainable solution to livelihoods' security risks, including food, health and education, these efforts should only be seen as complementary measures that must go along with other poverty reduction measures [38].

The findings on the health risks as drivers of forest dependence point to a situation of constraints on human wellbeing and productivity among the poor that is well framed within the international development policies, but still affects the poorest households. The challenge, however, remains that of implementation and monitoring of 
health risks that are still affecting the poorest residents. The proliferation of constraints on human health among most rural and poor perpetuates bad health, hunger and poverty [38]. The implications of these outcomes for natural resources use and conservation are dire and need to be explored to maintain the integrity and wellbeing of both the poor and the wildlife. In the recent past, integrated development and conservation programs have appeared to combine human needs into conservation strategies [32]. However most of these ICDPs have concentrated on income and consumption aspects of poverty, ignoring other dimensions of poverty such as health security risks and their implications for biodiversity conservation. The key problems with ICDPs, as reference [10] point out, is that they have not been linked conceptually to their conservation impacts. The findings of this study are a demonstration of the importance and need to explore and consider links between human health and forest dependence. The recent emergence of integrated Population, Health, and Environment (PHE) programs in biodiversity rich but poor countries provide hope [62]. Practitioners and policy makers at VNP and those involved in the ICDP in developing countries should tap into such PHE ideas and devise public health programs that provide the poorest households neighboring the forest areas with access to clean water and health care services.

The finding on food insecurity as a key driver of forest dependence also corroborates exploratory findings on the causes of forest dependence from a park management perspective. In addition, the finding of food insecurity as a driver of forest dependence in this study supports existing literature that forest dependence is a function of these households' need for resources to meet their subsistence needs [4] [18] [63]. Evidence exists that a household's access to food is determined by its means to produce, purchase, and gather food [64]. The food insecurity finding, therefore, is not surprising because first, most poor households (60 percent of the sample) near the park do not own land (see Table 2). For those with land, the production and livelihood means of poor households neighboring VNP are severely compromised by animal crop raiding. The only option left is to gather food from the park.

To address food insecurity associated with forest dependence problems at VNP, the park management and government policy makers need to understand the local conditions creating it. First, the crop-raiding problem and its impact on poor households needs to be specifically targeted and addressed because crop-raiding remains one of the key factor in human-wildlife conflicts [65] [66]. In Tanzania, for example, crop raiding was found to be a key source of human-wildlife conflict that resulted in a food security problem in Doma and Mukumi villages [6]. While the ongoing efforts to fence the park have appeared effective elsewhere [67], they do not provide a long-term solution [65] [66]. Various remedies to the crop-raiding problem, such as a change in cropping patterns, compensation, night vigils, fences and barriers, and introduction of non-edible crops have been proposed in the literature [6] [40]. While animal crop raiding compensation seems to be preferred [66] [68], it feeds into a complicated debate on compensation as a right or as consolation [6]. Ideally, a more long-term solution includes trust and confidence building through communication and partnerships with the most affected group of residents, the poor households, to enable a situation of improved tolerance for wildlife [6] [40] [65] [66]. Thus, animal crop raiding compensation should not be viewed as a right, but as a consolation because of the expectation it raises if it is viewed as a right, and the potential associated management problems it might create in poor communities. Additionally, efforts should be made to devise crop-raiding co-management strategies with the poor and most vulnerable households [6] [68] [69].

Second, the use and productivity of farmland owned by poor households must be improved to increase annual productivity. For example, poor and vulnerable households must be supported to invest in coping strategies aimed at improving agricultural productivity such as soil conservation and land use changes that create variations in cropping patterns [70] [71]. Third, for poor households without land, efforts must be made to identify and facilitate them to form and work in agricultural farming cooperatives. Such cooperatives can be supported to purchase land from which they can produce for their consumption needs and generate income. Such successful models of community self-sufficiency programs exist elsewhere [72]. For example in Luangwa Valley in Zambia, food insecure households were identified and trained in sustainable agricultural practices, which not only enabled them to meet their food needs but also allowed them to generate income from surplus produce sold to markets they were facilitated to access [72]. Borrowing from such business-based models promoting biodiversity conservation and community self-sufficiency has the potential to create a more sustainable solution to poverty and forest dependence [72]. However, efforts must be made at every stage of development of such conservation-oriented community agribusiness initiatives to build and maintain a documentation and monitoring 
mechanism to keep track of the biodiversity conservation link and to allow an evidence-based case to emerge and be replicated [14].

\section{Conclusion and Recommendations}

The main aim of this study was to identify household poverty dimensions that influence forest dependence among poor residents in proximity to the boundary of VNP. This was done in response to practitioners' concerns regarding biodiversity loss attributed to forest dependence at VNP. In addition, this study was a response to the calls in literature to identify linkages between biodiversity loss and poverty [17] [38]. The findings identified food, health, and education security risks to be the drivers of forest dependence among poor households neighboring VNP. Livelihoods' security risks associated with these three poverty dimensions include; insufficient annual production of food, high frequency of skipping meals in a day, poor access to clean water and health care services, high rate of children dropping out of school due to lack of educational materials, and high adult illiteracy among these poor households. These empirical findings place the SL framework at the center of the ongoing poverty and environmental debate in developing countries. As seen earlier in the paper, poverty is a complex phenomenon [16].

One of the key findings of this paper is that there is no difference among the effects each of the three dimensions (health, education and food) of household poverty and forest dependence at VNP. There are a number of implications of this finding. First, it demonstrates to practitioners and policy makers that health and education security are as important as food security in the effort to address forest dependence at VNP and other developing countries dealing with biodiversity loss resulting from human dependence on forest resources. Second, it raises several questions that are of interest for future research. For example, how does lack of educational materials and adult illiteracy among poor households influence forest dependence and environmental degradation? How do health risks such as access to water and health care services influence forest dependence? To what extent do forest resources act as traps for health, education and food risks to neighboring poor households? How can health and education be integrated in the biodiversity conservation programs, and what are the policy and regulatory frameworks needed for this to happen? It would also be important to investigate if and why income, employment and other "asset poverty" indicators may not significantly influence forest dependence. Do economic security risks such as employment, income, and assets mediate the relationship between household poverty and forest dependence?

Three key recommendations have been made to address the study findings. First, food security risks should be addressed by facilitating poor landowners with coping strategies such as changing cropping patterns and improving soil fertility to improve their agricultural productivity. Additionally, the crop-raiding problem must be managed by incorporating co-management strategies between park officials and poor households affected by animal crop raids. This will not only help to find a permanent remedy but also create a strong foundation for tolerance among the crop raiding victims to reduce human-wildlife conflict and promote human-wildlife coexistence. Second, poor households neighboring VNP, who do not possess land, should be facilitated to form cooperatives and use them to own land and engage in agricultural production for subsistence needs with potential to generate income from surplus production.

In summary, this paper calls for a change in how poverty and forest dependence are viewed. It suggests that poverty must be perceived beyond traditional macroeconomic conditions and be viewed as a multidimensional phenomenon involving not just income and consumption variables but also health and education. Poverty's relationship to forest dependence and biodiversity loss both in practice and in theory must encompass this view. Until this happens, efforts to relate poverty to forest dependence and biodiversity loss will remain abstract.

\section{Acknowledgements}

This paper is a result of research funded by United States Fish and Wildlife Services, Grant F12AP01121 and the Wildlife Conservation Society Research Fellowship Program. We acknowledge fieldwork assistance from Rica Rwigamba, Janvier Kwizera, Prosper Uwingeri, Edwin Sabuhoro, Jean Mwambusta and Sam Kacungira.

\section{References}

[1] Angelsen, A. and Kaimowitz, D. (1999) Rethinking the Causes of Deforestation: Lessons from Economic Models. The 
World Bank Research Observer, 14, 73-98. http://dx.doi.org/10.1093/wbro/14.1.73

[2] Angelsen, A. and Wunder, S. (2003) Exploring the Forest-Poverty Link. CIFOR Occasional Paper, 40, 1-20.

[3] De Sherbinin, A., VanWey, L.K., McSweeney, K., Aggarwal, R., Barbieri, A., Henry, S., Hunter, L.M., Twine, W. and Walker, R. (2008) Rural Household Demographics, Livelihoods and the Environment. Global Environmental Change, 18, 38-53. http://dx.doi.org/10.1016/j.gloenvcha.2007.05.005

[4] Masozera, M.K. and Alavalapati, J.R.R. (2004) Forest Dependency and Its Implications for Protected Areas Management: A Case Study from the Nyungwe Forest Reserve, Rwanda. Scandinavian Journal of Forest Research, 19, 85-92. http://dx.doi.org/10.1080/14004080410034164

[5] Nyaupane, G.P. and Poudel, S. (2011) Linkages among Biodiversity, Livelihood, and Tourism. Annals of Tourism Research, 38, 1344-1366. http://dx.doi.org/10.1016/j.annals.2011.03.006

[6] Vedeld, P., Jumane, A., Wapalila, G. and Songorwa, A. (2012) Protected Areas, Poverty and Conflicts: A Livelihood Case Study of Mikumi National Park, Tanzania. Forest Policy and Economics, 21, 20-31. http://dx.doi.org/10.1016/j.forpol.2012.01.008

[7] Wunder, S. (2001) Poverty Alleviation and Tropical Forests, What Scope for Synergies? World Development, 29, 1817-1833. http://dx.doi.org/10.1016/S0305-750X(01)00070-5

[8] Jodha, N. (1998) Poverty and Environmental Resource Degradation: An Alternative Explanation and Possible Solutions. Economic and Political Weekly, 2384-2390.

[9] Reardon, T. and Vosti, S.A. (1995) Links between Rural Poverty and the Environment in Developing Countries: Asset Categories and Investment Poverty. World Development, 23, 1495-1506. http://dx.doi.org/10.1016/0305-750X(95)00061-G

[10] Salafsky, N. and Wollenberg, E. (2000) Linking Livelihoods and Conservation: A Conceptual Framework and Scale for Assessing the Integration of Human Needs and Biodiversity. World Development, 28, 1421-1438. http://dx.doi.org/10.1016/S0305-750X(00)00031-0

[11] Cavendish, W. (2000) Empirical Regularities in the Poverty-Environment Relationship of Rural Households: Evidence from Zimbabwe. World Development, 28, 1979-2003. http://dx.doi.org/10.1016/S0305-750X(00)00066-8

[12] Bhandari, B. and Grant, M. (2007) Analysis of Livelihood Security: A Case Study in the Kali-Khola Watershed of Nepal. Journal of environmental Management, 85, 17-26. http://dx.doi.org/10.1016/j.jenvman.2006.07.010

[13] Sunderlin, W.D., Angelsen, A., Belcher, B., Burgers, P., Nasi, R., Santoso, L. and Wunder, S. (2005) Livelihoods, Forests, and Conservation in Developing Countries: An Overview. World Development, 33, 1383-1402. http://dx.doi.org/10.1016/j.worlddev.2004.10.004

[14] Sachs, J.D., Baillie, J.E., Sutherland, W.J., Armsworth, P.R., Ash, N., Beddington, J. and Gaston, K.J. (2009) Biodiversity Conservation and the Millennium Development Goals. Science, 325, 1502-1503. http://dx.doi.org/10.1126/science.1175035

[15] Beckley, T.M. (1998) The Nestedness of Forest Dependence: A Conceptual Framework and Empirical Exploration. Society Natural Resources, 11, 101-120. http://dx.doi.org/10.1080/08941929809381066

[16] Chambers, R. (1995) Poverty and Livelihoods: Whose Reality Counts? Environment and Urbanization, 7, $173-204$. http://dx.doi.org/10.1177/095624789500700106

[17] Vira, B. and Kontoleon, A. (2010) Dependence of the Poor on Biodiversity: Which Poor, What Biodiversity? In: Roe, D., Elliott, J., Sandbrook, C. and Walpole, M., Eds., Biodiversity Conservation and Poverty Alleviation: Exploring the Evidence for a Link, Wiley-Blackwell, Hoboken, 52-84.

[18] Bahuguna, V.K. (2000) Forests in the Economy of the Rural Poor: An Estimation of the Dependency Level. AMBIO: A Journal of the Human Environment, 29, 126-129.

[19] McSweeney, K. (2002) Who Is Forest Dependent? Capturing Local Variation in Forest-Product Sale, Eastern Honduras. The Professional Geographer, 54, 158-174. http://dx.doi.org/10.1111/0033-0124.00323

[20] Fisher, M. (2004) Household Welfare and Forest Dependence in Southern Malawi. Environment and Development Economics, 9, 135-154. http://dx.doi.org/10.1017/S1355770X03001219

[21] Chambers, R. and Conway, G. (1992) Sustainable Rural Livelihoods: Practical Concepts for the 21st Century.

[22] Ellis, F. (2000) The Determinants of Rural Livelihood Diversification in Developing Countries. Journal of Agricultural Economics, 51, 289-302. http://dx.doi.org/10.1111/j.1477-9552.2000.tb01229.x

[23] Frankenberger, T., Drinkwater, M. and Maxwell, D. (2000) Operationalizing Household Livelihood Security. Proceedings of a Report for the Forum on Operationalizing Participatory Ways of Applying Sustainable Livelihood Approaches, DfID/FAO, Rome.

[24] Scoones, I. (1998) Sustainable Rural Livelihoods: A Framework for Analysis. IDS Working Paper 72, Institute of De- 
velopment Studies, Brighton.

[25] Adhikari, B., Williams, F. and Lovett, J.C. (2007) Local Benefits from Community Forests in the Middle Hills of Nepal. Forest Policy and Economics, 9, 464-478. http://dx.doi.org/10.1016/j.forpol.2005.11.002

[26] Agrawal, A. and Redford, K. (2006) Poverty, Development, and Biodiversity Conservation: Shooting in the Dark? Wildlife Conservation Society Working Paper 26, Bronx, New York.

[27] Bush, G.K., Ikirezi, M., Daconto, G., Gray, M. and Fawcett, K. (2010) Assessing Impacts from Community Conservation Interventions around Parc National des Volcans, Rwanda.

[28] Nielsen, H. and Spenceley, A. (2010) The Success of Tourism in Rwanda, Gorillas and More. World Bank and the Netherlands Development Organization.

[29] Plumptre, A., Kayitare, A., Rainer, H., Gray, M., Munanura, I., Barakabuye, N. and Namara, A. (2004) The SocioEconomic Status of People Living near Protected Areas in the Central Albertine Rift. WCS, IGCP, CARE Uganda, Kampala.

[30] Gray, M., McNeilage, A., Fawcett, K., Robbins, M.M., Ssebide, B., Mbula, D. and Uwingeli, P. (2009) Censusing the Mountain Gorillas in the Virunga Volcanoes: Complete Sweep Method versus Monitoring. African Journal of Ecology, 48, 588-599.

[31] Archabald, K. and Naughton-Treves, L. (2001) Tourism Revenue Sharing around National Parks in Western Uganda: Early Efforts to Identify and Reward Local Communities. Environmental Conservation, 28, 135-149. http://dx.doi.org/10.1017/S0376892901000145

[32] Blomley, T., Namara, A., McNeilage, A., Franks, P., Rainer, H., Donaldson, A. and Sandbrook, C. (2010) Development and Gorillas? Assessing Fifteen Years of Integrated Conservation and Development in Southwestern Uganda. IIED.

[33] Brown, K. (2002) Innovations for Conservation and Development. The Geographical Journal, 168, 6-17. http://dx.doi.org/10.1111/1475-4959.00034

[34] Kiss, A. (2004) Is Community-Based Ecotourism a Good Use of Biodiversity Conservation Funds? Trends in Ecology \& Evolution, 19, 232-237. http://dx.doi.org/10.1016/j.tree.2004.03.010

[35] Alkire, S. and Santos, M.E. (2011) Acute Multidimensional Poverty: A New Index for Developing Countries.

[36] Goedhart, T., Halberstadt, V., Kapteyn, A. and Van Praag, B. (1977) The Poverty Line: Concept and Measurement. Journal of Human Resources, 12, 503-520. http://dx.doi.org/10.2307/145372

[37] Chambers, R. (1983) Rural Development: Putting the Last First (Volume 198). Longman, London.

[38] Sachs, J., McArthur, J.W., Schmidt-Traub, G., Kruk, M., Bahadur, C., Faye, M. and McCord, G. (2004) Ending Africa's Poverty Trap. Brookings Papers on Economic Activity, 2004, 117-240. http://dx.doi.org/10.1353/eca.2004.0018

[39] Frankenberger, T.R. and McCaston, M.K. (1998) The Household Livelihood Security Concept. Food Nutrition and Agriculture, 30-35.

[40] Ashley, C., Carney, D. and Britain, G. (1999) Sustainable Livelihoods: Lessons from Early Experience (Volume 94). Department for International Development, London.

[41] Hackel, J.D. (1999) Community Conservation and the Future of Africa’s Wildlife. Conservation Biology, 13, $726-734$. http://dx.doi.org/10.1046/j.1523-1739.1999.98210.x

[42] Tumusiime, D.M., Vedeld, P. and Gombya-Ssembajjwe, W. (2011) Breaking the Law? Illegal Livelihoods from a Protected Area in Uganda. Forest Policy and Economics, 13, 273-283. http://dx.doi.org/10.1016/j.forpol.2011.02.001

[43] Margolius, R. and Salafsky, N. (2001) Guide to Threat Reduction Assessment for Conservation. Biodiversity Support Program, Washington DC.

[44] Dewi, S., Belcher, B. and Puntodewo, A. (2005) Village Economic Opportunity, Forest Dependence, and Rural Livelihoods in East Kalimantan, Indonesia. World Development, 33, 1419-1434. http://dx.doi.org/10.1016/j.worlddev.2004.10.006

[45] Overdevest, C. and Green, G.P. (1995) Forest Dependence and Community Well-Being: A Segmented Market Approach. Society \& Natural Resources, 8, 111-131. http://dx.doi.org/10.1080/08941929509380906

[46] Gram, S. (2001) Economic Valuation of Special Forest Products: An Assessment of Methodological Shortcomings. Ecological Economics, 36, 109-117. http://dx.doi.org/10.1016/S0921-8009(00)00213-5

[47] Adams, W.M. and Infield, M. (2003) Who Is on the Gorilla's Payroll? Claims on Tourist Revenue from a Ugandan National Park. World Development, 31, 177-190. http://dx.doi.org/10.1016/S0305-750X(02)00149-3

[48] Diamantopoulos, A. and Winklhofer, H.M. (2001) Index Construction with Formative Indicators: An Alternative to Scale Development. Journal of Marketing Research, 38, 269-277. http://dx.doi.org/10.1509/jmkr.38.2.269.18845 
[49] Jarvis, C.B., MacKenzie, S.B. and Podsakoff, P.M. (2003) A Critical Review of Construct Indicators and Measurement Model Misspecification in Marketing and Consumer Research. Journal of Consumer Research, 30, 199-218. http://dx.doi.org/10.1086/376806

[50] Creswell, J.W. (2009) Research Design: Qualitative, Quantitative, and Mixed Methods Approaches. Sage Publications, Inc., Thousand Oaks.

[51] NISR (2012) The Evolution of Poverty in Rwanda from 2000-2011. National Institute of Statistics, Rwanda.

[52] Dillman, D.A., Smyth, J.D. and Christian, L.M. (2009) Internet, Mail, and Mixed-Mode Surveys: The Tailored Design Method. Wiley, Hoboken.

[53] DeVellis, R.F. (2011) Scale Development: Theory and Applications (Volume 26). Sage Publications, Inc., Thousand Oaks.

[54] Groves, R.M., Fowler, F.J., Couper, M.P., Lepkowski, J.M. and Singer, E. (2009) Survey Methodology (Volume 561). John Wiley \& Sons Inc., Hoboken.

[55] Byrne, B. (1998) Structural Equation Modeling with LISREL, PRELIS, and SIMPLIS: Basic Concepts, Applications, and Programming. Lawrence Erlbaum, Mahwah.

[56] Kline, R.B. (2011) Principles and Practice of Structural Equation Modeling. Guilford Press, New York.

[57] Hu, L. and Bentler, P.M. (1999) Cutoff Criteria for Fit Indexes in Covariance Structure Analysis: Conventional Criteria versus New Alternatives. Structural Equation Modeling: A Multidisciplinary Journal, 6, 1-55. http://dx.doi.org/10.1080/10705519909540118

[58] Mamo, G., Sjaastad, E. and Vedeld, P. (2007) Economic Dependence on Forest Resources: A Case from Dendi District, Ethiopia. Forest Policy and Economics, 9, 916-927. http://dx.doi.org/10.1016/j.forpol.2006.08.001

[59] Robinson, N.A., Hassan, P. and Burhenne-Guilmin, F.O. (1993) Agenda 21 \& the UNCED Proceedings (Volume 4). Oceana Publications, New York.

[60] Sachs, J.D. and McArthur, J.W. (2005) The Millennium Project: A Plan for Meeting the Millennium Development Goals. The Lancet, 365, 347-353. http://dx.doi.org/10.1016/S0140-6736(05)17791-5

[61] Wagstaff, A. (2004) The Millennium Development Goals for Health: Rising to the Challenges. World Bank.

[62] De Souza, R.M., Williams, J.S. and Meyerson, F.A.B. (2003) Critical Links: Population, Health, and the Environment (Volume 58). Population Reference Bureau, Washington DC.

[63] Wilkie, D.S. and Carpenter, J.F. (1999) Bush Meat Hunting in the Congo Basin: An Assessment of Impacts and Options for Mitigation. Biodiversity \& Conservation, 8, 927-955. http://dx.doi.org/10.1023/A:1008877309871

[64] Frankenberger, T.R. and Goldstein, D.M. (1990) Food Security, Coping Strategies and Environmental Degradation. Arid Lands Newsletter, 30, 21-27.

[65] Naughton-Treves, L. (1998) Predicting Patterns of Crop Damage by Wildlife around Kibale National Park, Uganda. Conservation Biology, 12, 156-168. http://dx.doi.org/10.1046/j.1523-1739.1998.96346.X

[66] Pienkowski, M., Watkinson, A., Kerby, G., Naughton-Treve, L., Chapman, C. and Wrangham, R. (1998) Temporal Patterns of Crop Raiding by Primates: Linking Food Availability in Croplands and Adjacent Forest. Journal of Applied Ecology, 35, 596-606. http://dx.doi.org/10.1046/j.1365-2664.1998.3540596.x

[67] Tweheyo, M., Hill, C.M. and Obua, J. (2005) Patterns of Crop Raiding by Primates around the Budongo Forest Reserve, Uganda. Wildlife Biology, 11, 237-247. http://dx.doi.org/10.2981/0909-6396(2005)11[237:POCRBP]2.0.CO;2

[68] Sekhar, U. (2003) Local People’s Attitudes towards Conservation and Wildlife Tourism around Sariska Tiger Reserve, India. Journal of environmental Management, 69, 339-347. http://dx.doi.org/10.1016/j.jenvman.2003.09.002

[69] Sekhar, N.U. (1998) Crop and Livestock Depredation Caused by Wild Animals in Protected Areas: The Case of Sariska Tiger Reserve, Rajasthan, India. Environmental Conservation, 25, 160-171. http://dx.doi.org/10.1017/S0376892998000204

[70] Clay, D.C. (1995) Fighting an Uphill Battle: Population Pressure and Declining Land Productivity in Rwanda. Research in Rural Sociology and Development, 6.

[71] Boserup, E. and Kaldor, N. (1965) The Conditions of Agricultural Growth. Aldine, Chicago.

[72] Lewis, D., Bell, S.D., Fay, J., Bothi, K.L., Gatere, L., Kabila, M. and Moraru, C.I. (2011) Community Markets for Conservation (COMACO) Links Biodiversity Conservation with Sustainable Improvements in Livelihoods and Food Production. Proceedings of the National Academy of Sciences, 108, 13957-13962.

http://dx.doi.org/10.1073/pnas.1011538108 
Scientific Research Publishing (SCIRP) is one of the largest Open Access journal publishers. It is currently publishing more than 200 open access, online, peer-reviewed journals covering a wide range of academic disciplines. SCIRP serves the worldwide academic communities and contributes to the progress and application of science with its publication.

Other selected journals from SCIRP are listed as below. Submit your manuscript to us via either submit@scirp.org or Online Submission Portal.
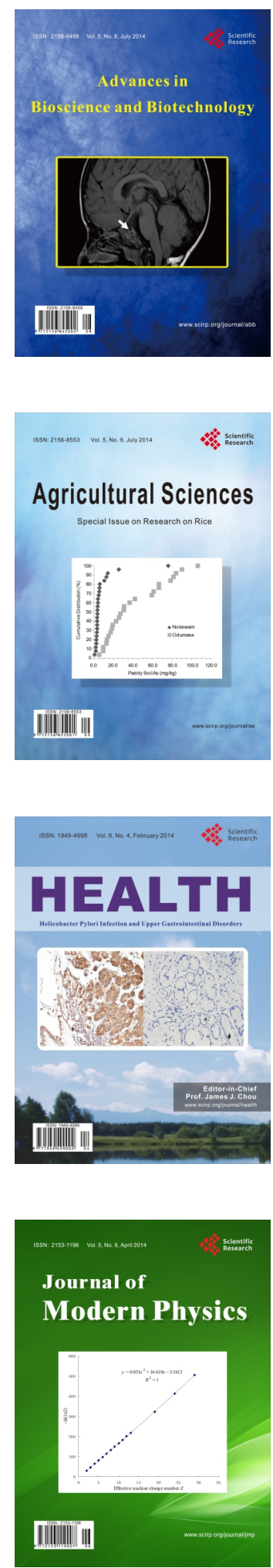
